\title{
Modernity and Tradition in the Context of Erbil Old Town
}

\author{
Asma Ahmed Mustafa Al Jaff ${ }^{1}$, Mohammed Sabah Al Shabander ${ }^{2}$, Havva ALKAN BALA ${ }^{3, *}$ \\ ${ }^{1}$ Selcuk University, Konya, Turkey \\ ${ }^{2}$ Higher College of Technology, Muscat, Oman \\ ${ }^{3}$ Selcuk University, Konya, Turkey \\ *Corresponding author: asmajaff1990@hotmail.com
}

\begin{abstract}
Daniel Libeskind designs and implements structures that are very different from each other and form contrasts in the designs he has made in historical buildings and circles. As in the different parts of the world, he designed a museum building in the city of Erbil with similar design philosophy. This structure shows a remarkable approach in terms of design criteria, architectural understanding and new conditions of building in historical environment. In this paper, the example of Erbil city museum was taken into consideration, new building design methodologies in the historical environment and evaluations about the concept of urban conservation were made. Daniel Lisbeskind, designed carried out in historic buildings and environment, such differential in the city texture (tissue), forming contrasts, structures were designed and applied. As with the world also designed a museum building in Erbil with similar design philosophy. This building, the design criteria, architectural understanding, main idea and in historical environment new construction conditions, it shows a remarkable approch in the context. Within this article, by taking samples Erbil city museum, historic environment new building design methodology and assessments have been made to the concept of urban conservation.
\end{abstract}

Keywords: Daniel Libeskind, museum, Erbil Old Town, historical environment

Cite This Article: Asma Ahmed Mustafa Al Jaff, Mohammed Sabah Al Shabander, and Havva ALKAN BALA, "Modernity and Tradition in the Context of Erbil Old Town." American Journal of Civil Engineering and Architecture, vol. 5, no. 6 (2017): 217-224. doi: 10.12691/ajcea-5-6-1.

\section{Introduction}

The constructions and environments that the societies produce in different periods of time are concrete manifestations of the culture and historical background of that society. Such environments convey the experiences of the society in which they are produced, their existence and destruction, their cultural and social lives to today's generations. The values transferred may be both material and non-tangible spiritual values [1]. The circles of such structures are a recognized general judgment that they must be protected because of the bridge they have built between the past and the future. Historical environments with these bridges or areas of interaction reflect the temporal, spatial and physical differences between past and present. For this reason, decisions about historical environments are handled with care and care in order not to cause permanent damage that can not be reversed. The most important of the decisions made about the historical environment are the approaches to new construction that will be realized in these areas. In new constructions, today's criteria must be adhered to and must be designed without departing from historical values. Thus, with these approaches, the destruction of cultural identity in the historical environment will be prevented and it will be ensured to be transmitted to future generations.
Arabacioglu and Aydemir [2] emphasized the importance of being involved in decision-making about historical environments and stated that the mistakes made in these areas could cause the disappearance of past civilizations reaching to daylight, loss of physical spaces, loss of special qualities and formation of rootless and identityless social structure.

According to Taebi and A. Bala [3], if we consider the city as a living organism, the social, cultural and spatial context of the people make up the memory of that city. The social memory is the extension of the social structure which is usually the relation of the space with the public space. Establishing a proper physical and social order for social interaction and events will take place by establishing appropriate conditions for documenting memories and communicating them to future generations. The place of residence, the sense of belonging in the place, the historical buildings, the names of the places / streets / neighborhoods, the places where the social events are experienced, the meeting places such as bus station, train station, airport where the transportation networks meet with the city, sculptures, symbolic constructions and especially monumental buildings are the key components of urban memory.

According to Tekeli [4], it emphasizes the necessity of bringing a healthy history to people living in society. In order for the person to be able to socialize healthily, the environment they live in must constantly convey to them 
the signs of the historical past. A person who socializes by living in an environment that carries past signs will have a cultural continuity and history consciousness. The continuity envisioned here is not a nostalgic craving for carrying past the symbols of the past in the new life, or for the past to be revived.

These investigations show that deformations, worn-outs and losses occurring in historical circles change not only the loss of the physical structure of the historical structure and the environment, but also the social and cultural structure of the society within it. It can be observed that the original social structure in these regions has been changed and the general social structure of the city has been affected negatively by the user profile [5]. This social change prepares the ground for the breakdown of intellectual and physical communication between the original city and the old city, and attempts to maintain its presence in the cities as idle spaces without historical surroundings.

The most important misconceptions that have been made in order to solve the problems that the historical enclaves that have become problematic areas in the city are to be completely destroyed and to have a preliminary plan for new constructions. According to Zeren [6], the historical environment is the remaining settlements and remains from past civilizations. When the historical environment is referred to, it is meant more urban sites, while rural, historical and archaeological sites are also considered within this context. The historical surroundings are a bustle, and the whole of its fragments, the buildings that make up that texture, the rich edifices that accommodate various styles and forms, the admirable appearances, the curved streets that allow pleasant surprise. Architectural styles, space designs and construction techniques, which are located in historical surroundings and which are an integral part of this whole building, are evaluated as historical data defining the architectural identity of the area.

However, it is important in the context of the concept of protection to avoid destruction in historic surroundings, to ensure architectural and cultural continuity, to correct the physical conditions of historical building for the preservation of existing physical spaces, and to reuse it with appropriate proper or appropriate function.

In 1946, the United Nations Educational, Scientific and Cultural Organization (UNESCO) was established in London. The Convention on the Protection of the World Cultural and Natural Heritage, which was signed by UNESCO in 1972 and which has been signed by several member countries of the United Nations, has decided that the elements of cultural and natural heritage have an extraordinary prevalence and that all humanity should be protected as part of the world heritage. The World Heritage Foundation (WHF) was established on the basis of the contract and the purpose of preserving 250 cultural assets. Another meeting held in the same year, "Recommendations for the Protection of Cultural and Natural Heritage at National Level", aims at preserving, preserving and promoting the cultural and natural heritage; it is said to be the development of mankind. At the UNESCO General Conference, the "Convention on the Protection of the World Cultural and Natural Assets", which was adopted in 1972 as a member state, It is divided into "Cultural Heritage" and "Natural Heritage" and "Cultural Heritage" is classified in itself. According to this: Cultural Heritage; Monuments: Architectural works, sculptures and paintings with an unusual historical, artistic or scientific value, archaeological elements and structures, inscriptions, cave and element groups, building communities: architects, associations or historical or artistic separate or unified communities of architecture with an extraordinary universal value from the scientific point of view. Sitler: Described as areas of human product that have an unusual universal value in terms of history, aesthetics, ethnology or anthropology, or common works of human and nature and archeological sites. In 1972, UNESCO classified the protected assets in the same way as "cultural heritage and natural heritage" [7] in the same way as the "Recommendations for the Protection of Cultural and Natural Heritage at National Level".

In resolutions on "Protection of Historical Areas and Recommendations on Contemporary Issues" embodied in UNESCO's meeting in Nairobi in 1976, the definition and purpose of the conservationist has been evaluated as "the identification, repairs, sanitization, maintenance and revitalization of the historical or traditional areas and environments". The proposals expressed in these decisions are explained in the introduction section of the guardian. In this chapter, we will look at the historical milieu of history, taking into account the fact that historical environments are everywhere a part of people's daily surroundings, represent the living entity of the past that constitutes them, provide diversity to respond to the diversity in society in life, as well as the preservation of values and a humanitarian dimension. the reasons for the preservation of these living witnesses of past days for the people and societies that found their foundation stones and cultural assets in the face of the similarity and identity deception dangers increasingly brought about by the standardization of our times that they constitute the most concrete witnesses of the diversity and richness of social, it is indicated. In the definitions section of the proposed proposals; archeological, architectural, prehistoric, historical, aesthetic, or socio-cultural aspects of the protected area 16 are emphasized. In the general principles section; there is an explanation of the reasons why the preservation of historical sites today is to protect and develop the cultural and social values of the countries so that the cultural heritage of the world can be contributed to the architectural enrichment [8].

These practices prepare the ground for the transfer of the cultural accumulation of the societies to future generations, allowing the city to retain its centuries-old identity and allowing for the revitalization of urban spaces that have now become obsolete. Cultural historical assets should be seen as a legacy to be transferred to future generations, rather than being seen as a heritage from the past and now banned by annihilation and to be consumed, and should be an approach that should be more involved in society. [9]. In addition to the preservation of historical environments, the redesign of the lost areas in these environments, the filling of the urban voids with losses, the use of design approaches in new applications, the formal relationship between historical environment and new structures, decision makers and designer and urban planners It's a challenge. Since cultural issues such as lack 
of education, lack of awareness, lack of awareness of protection, and lack of awareness of the public, which cause problems in the preservation of historical urban fabric, cultural investments can provide important contributions in improving the viewpoints of the persons concerned (values, decision makers, implementers, [10]).

The new structures to be built in this context are required to be in harmony with the historical environment and to provide an integrity, meeting today's needs and sustainable. When designing a new structure in historical surroundings, the modern structure must be adapted to the historical surroundings with its features such as form, texture, scale, color, and historical structure, and the emerging new structure shows the personality, culture and identity of that society. However, new structures gain value in the historical environment. Considering the historical and cultural background of Erbil Citadel as an important factor, the Erbil Kurdish Museum was evaluated within the framework of these main ideas and evaluations related to the relationship between historical environment factor and new design were made.

\section{New Building Design Criteria in Historical Environment}

Korumaz [11], in an Evaluation Study on Additional Floor Applications in Some Historical Buildings in Istanbul, categorized the design criteria of applications in the historical environment in general.

- To imitate the historical environment completely,

- Approaches that take into account the historical environment and seek harmony (to simulate, stay neutral, and interpret the historical environment)

- Performing contrast and deconstructivist applications.

In the context of these evaluations, the design can be summarized as follows:

The new structure, historical surroundings and constructions that make up the historical surroundings enable adaptation to today's life, the continuity of their use, the present-day space concept and the spaces that encompass the needs of this concept. Historical structures need to go through many processes in order to be able to respond to the ages. It is to be able to adopt the new way of life and work together in the cycle that it has. On the other hand, this situation has the opposite system to those applied to the abandoned neighborhood, which does not respond to the requirements of the times. The structured structure, form, function, scale, color and texture. In the intervention of the designer in the historical surroundings, the new buildings need to produce structures respecting the old, living at the time they are, harmonizing with the present environment, imitating, living alive. Considering this system, every structure applied can have the principle of survival while living. [12]

\section{Historical Structure of Erbil Citadel and Its Environs}

The town of Arbil and its surroundings have been home to many civilizations for centuries and are still an important cultural heritage of today with different traces of these cultures. Due to this reason, the building complex has been taken on UNESCO's list of cultural and historical heritage, restoration work started by UNESCO in 2007 and still works today.

Erbil Citadel, which hosts many rulings from the historical point of view, is located in Erbil, Iraq's 4th largest city. In the city where the majority of the Kurdish community is located, there are also many ethnic groups such as Turkmen, Assyrians, Christians and Arabs. The city of Erbil, the Assyrians, the Arabs, the Seljuks and the Ottoman Turks. Urban life in Arbil BC It dates back to 6000 years. The month is the oldest permanent settlement in the world at the time. In the center of the city is the Arbil Citadel, which is estimated to be close to 7000 years. The Erbil fortress is situated above the city and on a hill dominating the whole city. It has an elliptical form and its height is approximately $28-32$ meters. The east-west axis is about 430 meters long and the north-south axis is about 340 meters. The castle has an area of 10 hectares. The castle, which dominates the silhouette of the city, also reveals its presence in the formation of new structures around it. Citadel Erbil became the most important factor in the planning and urban development of the city, and it was the focus point in the radial development of the city (https://en.wikipedia.org/wiki/Citadel_of_Erbil). The fact that the city is located at the center of the city has made it important for centuries to be preserved, thus playing an important role in protecting the city's general identity.

In the citadel there are more residential areas. But after the Ottomans captured Erbil, the social structure within the castle was differentiated into three regions. These are the Saray, Takya and Tophane regions. In the palace district there were families belonging to important palace members, in Takya there were houses of religious men of dervishes and in Tophane there were artisans and farmers (Figure 1).

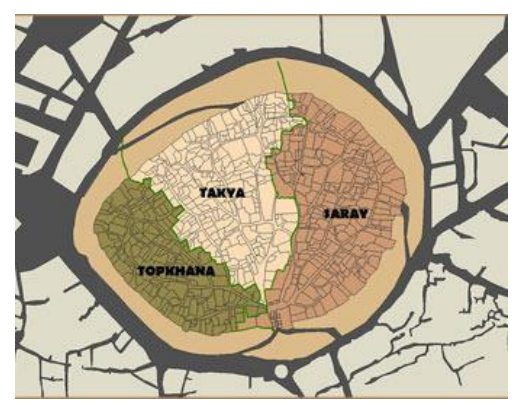

Figure 1. Social classes in Erbil Citadel after the Ottomans (http://www.erbilcitadel.org/fileup/60mahallas-01.jpg)

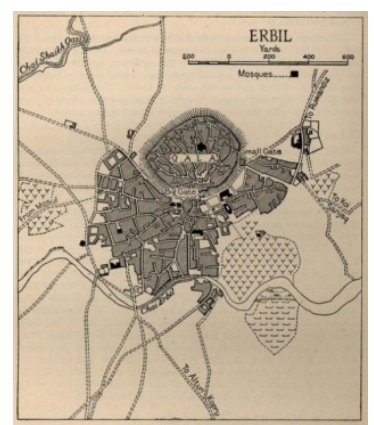

Figure 2. Master reconstruction plan of Erbil city 1944 (Map of Erbil city, c. 1920 (from: Naval Intelligence Division Geographical Handbook Series - Iraq and the Persian Gulf, Oxford 1944) (nomination of citadel Erbil) 


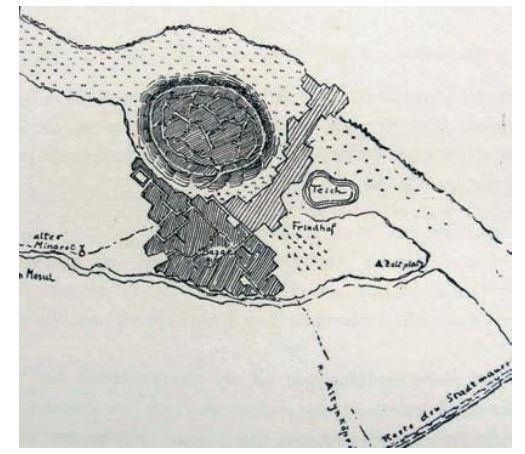

Figure 3. Sketch map of Erbil city, c. 1907-8 (From: Sarre and Herzfeld, 1920) (Nomination of citadel Erbil)

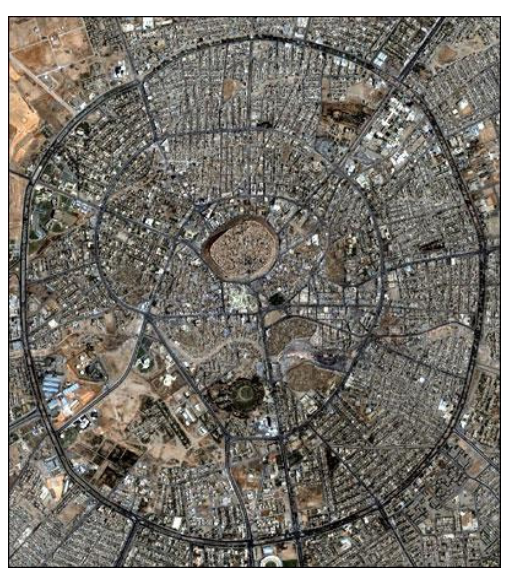

Figure 4. aerial photo of the city of Arbil, radial urban texture (Google Earth, 11.03.2016)
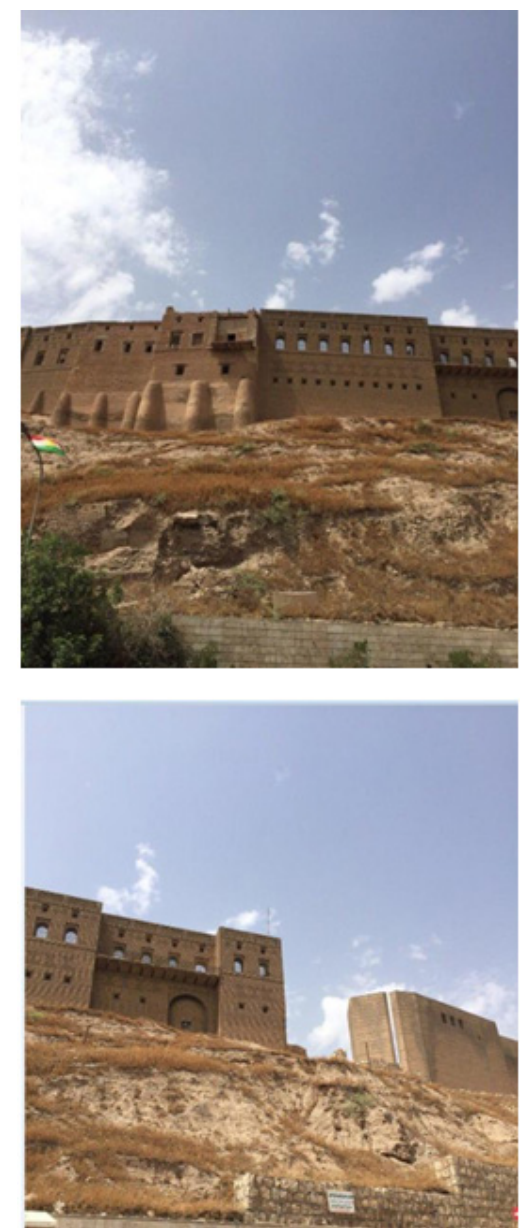

Figure 5. General View of Erbil Castle (Personal archive, 2016)

\section{Architectural Properties and Present Situations of the Erbil Citadel and the Fortresses}

-General urban texture,

The inner city of Erbil is typically a castle town. It consists of tight, narrow, winding streets that try to use the limited space as efficiently as possible.

- Examples and characteristics of civil architecture,

The existing dwellings are usually single or double storeys, with bricks in construction and rubble in some buildings (Figure 6). The houses are usually located around courtyards surrounded by high walls. The windows in the houses usually look at the courtyard, and the windows are organized according to the directions.
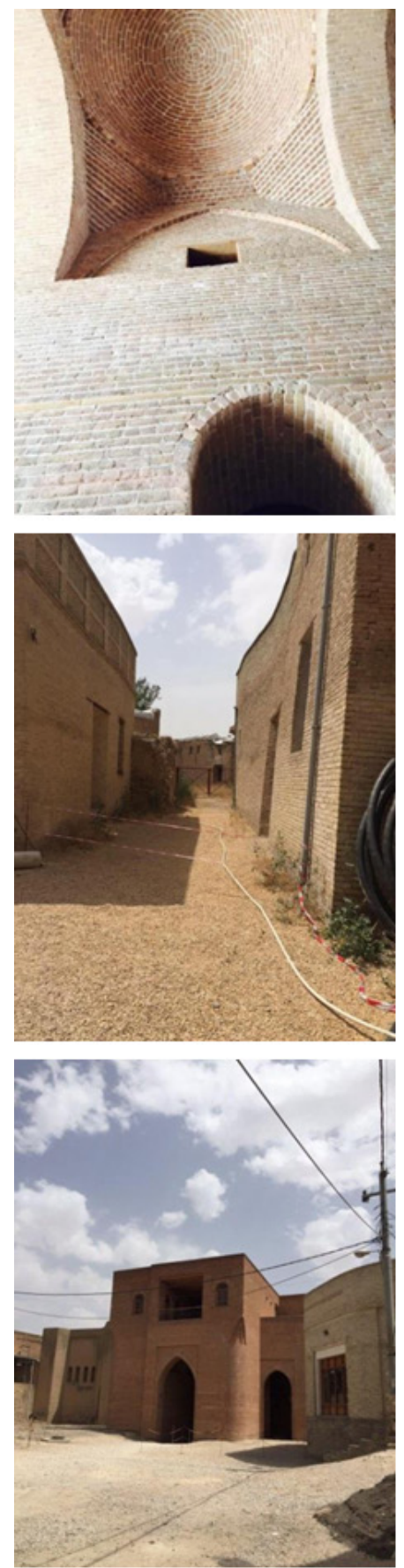

Figure 6. Materials and details of structures in Arbil (Personal archive, 2016) 
The open and semi open spaces are organized in the residence for hot and arid climate, the most important of which are the semi-open spaces with raised ibis and balustrades. In these areas, brick materials are used in place, while the building material is usually stone.

In the houses of Erbil Citadel, the ornaments are placed in the inner and outer places. While stone decoration items are used in the houses that give way to the street, decoration elements are usually found around the cabinets and niches in the interiors.

- Monuments and their properties,

The castle also has a mosque and a bath in daily history as well as in daily life.

- Current Status of the Castle

Over time, Erbil Castle has been subjected to considerable deformations. The most important reasons for this deformation are: changes in living conditions, economic inadequacy, wrong restoration practices, and the fact that the society is not conscious of the historical structure.

\section{Reuse Process and Erbil Citadel}

It has been thought that the citadel should be reactivated in order to overcome these problems, it is planned to organize cultural activities, educational units, museums, otters and cafeterias in the castle.
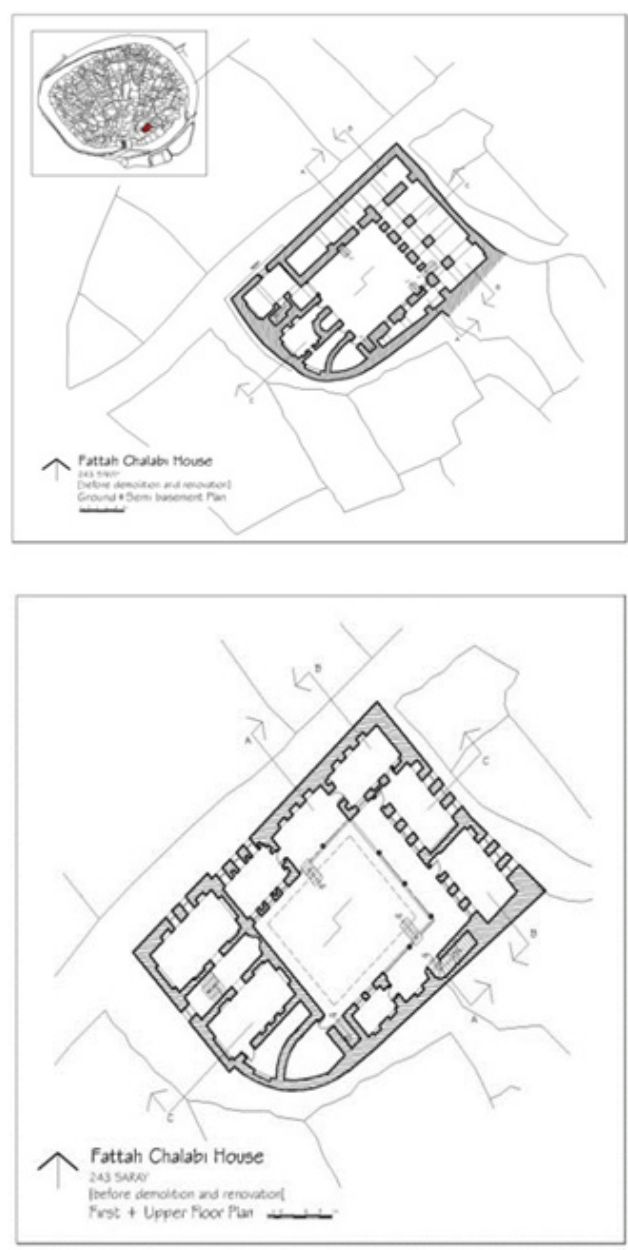

Figure 7. Fattah Chalabi house entrance and first floor existing plan before renovation and demolition

(http://www.erbilcitadel.org/Map/243 Saray.php)
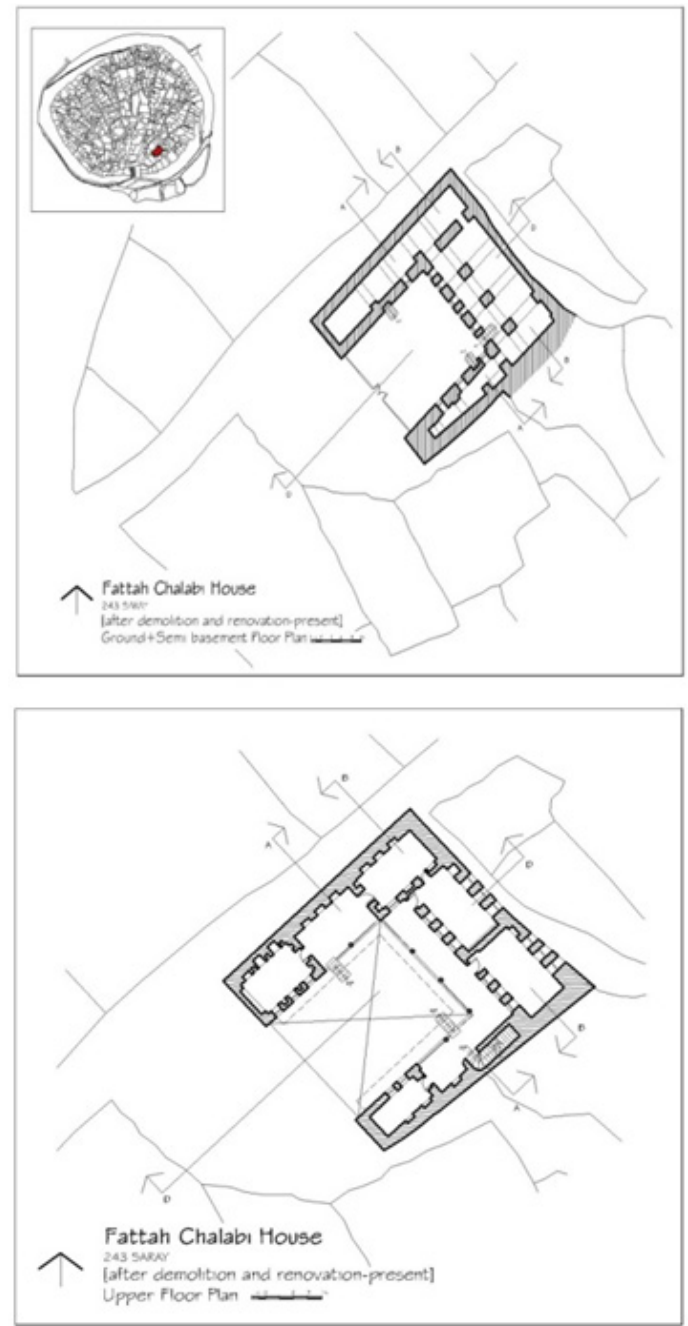

Figure 8. Fattah Chalabi house destroyed after the last re-entry and first floor existing plan (http://www.erbilcitadel.org/Map/243_Saray.php)
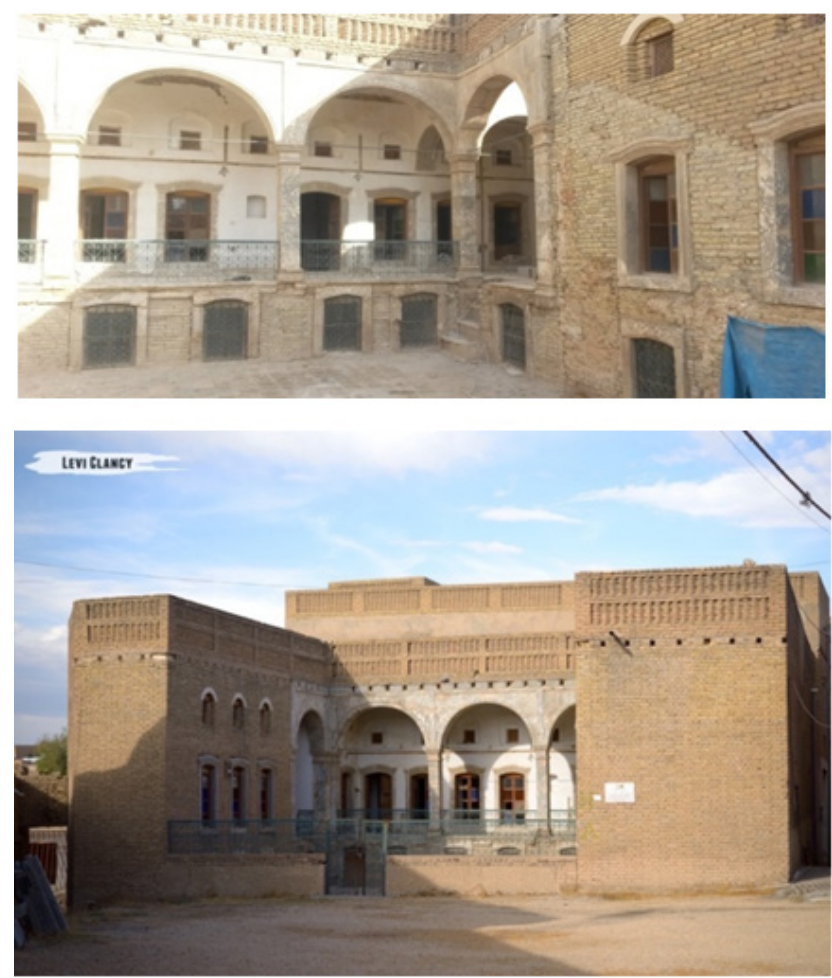

Figure 9. The next appearance from the new (http://levi.life/kurdistangovernment/hawler-governorate/hawler/erbil-citadel/houses/) 


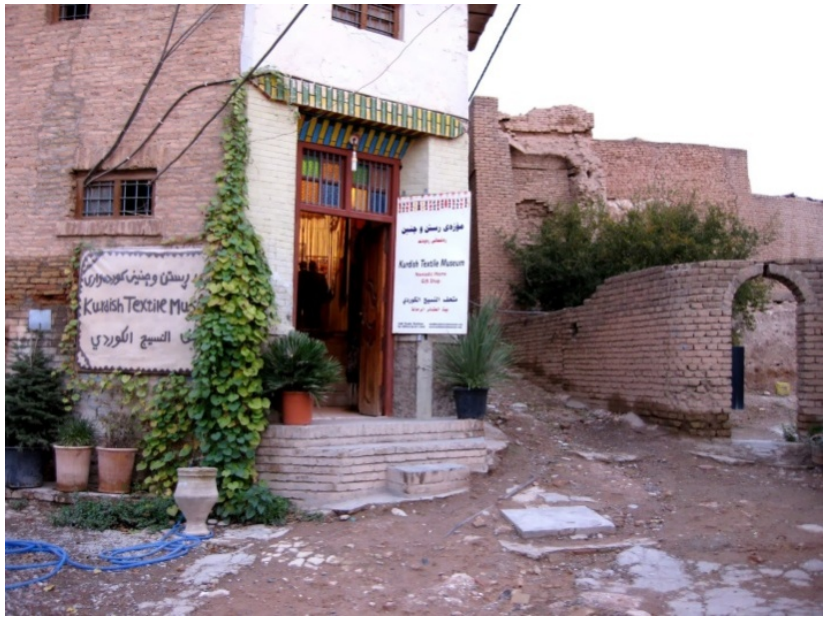

Picture 10. Different types of houses in the residence (http://kurdistanart.blogspot.com.tr/2013/10/kurdish-textile-museumerbil.html)

Reconsideration is part of cultural continuity, not only in terms of preservation of architectural heritage, but also an example of new practices.

(Arabacioglu and Aydemir (2007)) In this way, there will be mobility in the environment in terms of economy,
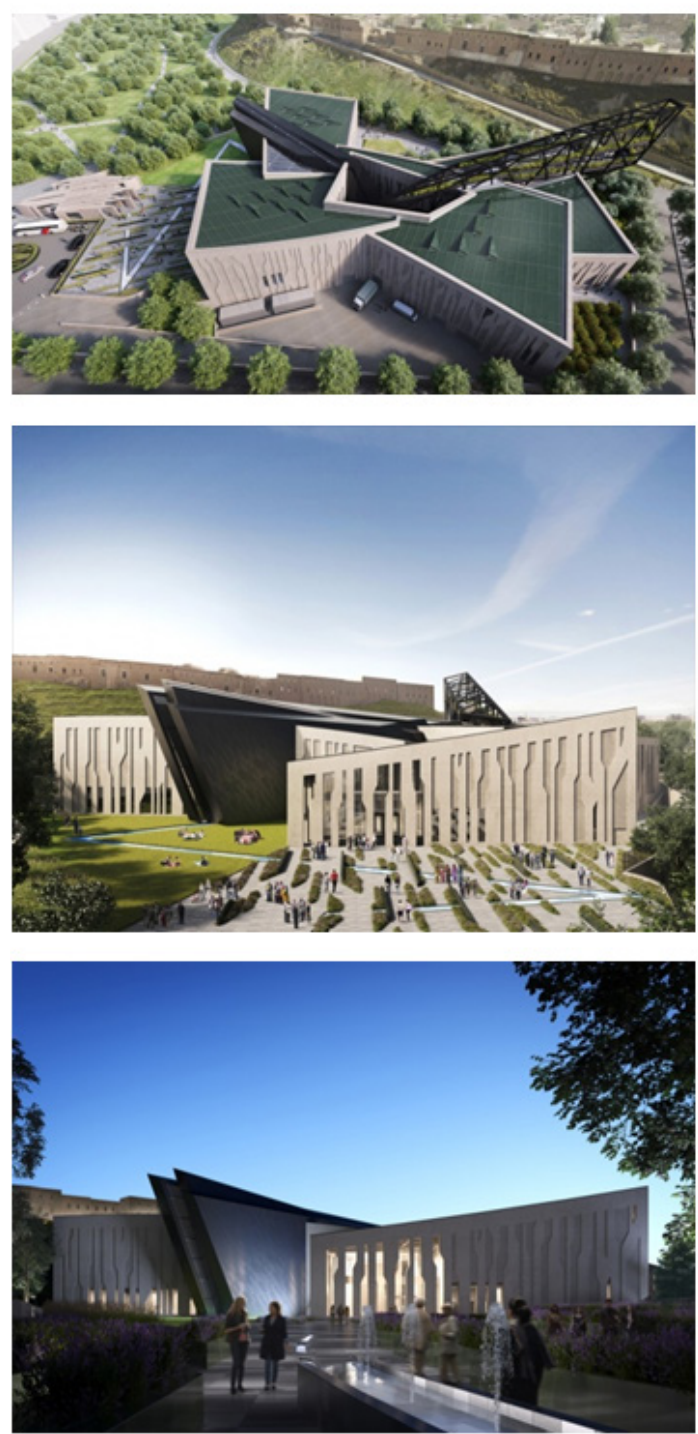

and culture exchange between societies will be done from a social perspective.

\section{Modern Building in Erbil Citadel 'Kurdistan Museum'}

Relation with the Erbil Citadel

One of the most important functions of the Erbil Citadel re-functioning activities is the Kurdistan Museum to be built in this area. The project, designed by Daniel Libeskind Studio, will be an important architectural element in the region. The project will take place as Kurdistan Regional Government and RWF World stakeholder.

Importance of Cultural Aspects

The museum structure will be constructed in a multicultural area. The museum building will be a quality that will introduce Kurdish culture, history and art together with the cultures there and give a vision to the world.

Libeskind describes the purpose of the Kurdish museum as a rich culture that reflects the spirit of the Kurdish people, and a structure that will express the future of Kurdistan.
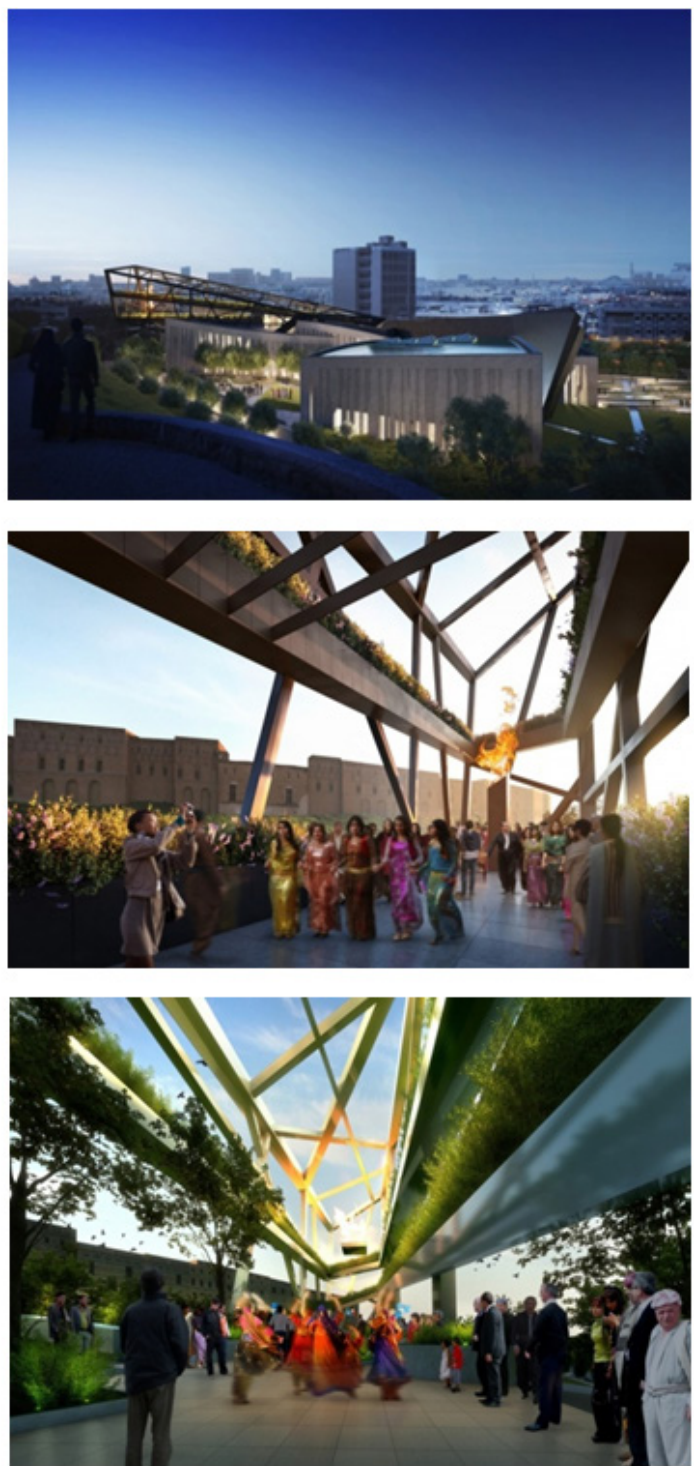

Figure 11. Images of the Kurdistan Museum Project (http://libeskind.com/) 
Emotional Infrastructure Project

Two extreme emotions are considered as the main theme in design. While sadness and tragedy reflect the experiences of the past, joy and hope describe the future of the people. Daniel Libeskind, who designs the architecture around lines, distorted angles, intersecting geometries and gaps through the concepts of 'absence', 'lost' and 'memory', is undoubtedly one of the masters who influence architecture theory and practice with its multidisciplinary architectural and radical approaches.

Physical Properties, Location Definitions

In terms of location, the museum which will be built in the area where the governorship building located next to the historic Erbil citadel is located will have an area of $150.000 \mathrm{~m}^{2}$. The museum has permanent and temporary exhibitions, educational theater, a multimedia education center, a large archive and meeting room of Kurdish history.

The concept of the museum represents four Kurdish ethnic groups (Turkey, Iran, Syria and Iraq). These four intersecting divisions divide themselves into two, crossing into the past and future of Kurdistan. Emotional dichotomy exists between these two areas, while the opaque mass (The Line Anfal) symbolizes the genocides of Saddam Hussein (The Liberty Line), and it gradually grows in the form of a cage, telling about the freedom of the Kurdish people. This area also has fire and green structures that represent the 'eternal flame' nevro that symbolizes the Kurdish culture. At the junction of these two lines, in the center of the museum, the courtyard was built as it was in the past built structures. In landscaping, water is integrated with the water and is inspired by the rivers and valleys that exist in the area. It is also aimed at the cafeteria, picnic areas, people gathering and meeting area at the same time in the landscaping area. The construction of the museum is to be made after the political infrastructure of the region has normalized.

The Kurdish museum will influence the region in economic, social and political terms. In this context, the museum will provide economic vitality by supporting the city's future tourist activities and contribute to the positive change of the social structure around the castle. On the political side, it will be a window that shares the experiences of the region with the political situation and the historical world.

\section{New Building in Historical Environment and Erbil Kurdish Museum}

Arbil Citadel and its surroundings are one of the structures that have a historical texture and architectural characteristics. The main purpose of the museum in this context is to address the cultural values in society and also to be morphologically, geographically and socially responsible for its position. Due to the fact that the location of the project is at the center of the city of Erbil, both the history of the city and its position beside the ruins of the city have led to the unification of the relationship with the place of the project, leading to the foreground. With the evaluations made, the past and present situation of the project area was investigated and contributed to the revitalization of the area around the historic Arbil castle with a modern contemporary building. The museum, planned to be built under the ruins of Arbil, is designed to maintain its sustainability in the vicinity of its historical texture as well as in its surroundings.

\section{Discussion}

What are the positive and negative aspects of the project in the context of new building design in historical surroundings?

-Good aspects

The museum to be built will prevent the revival of historical identity, which will cause revival of social, cultural and economical revival. At the same time, it will gain value in the environment due to being the first museum in the region.

-criticized aspects

The museum to be built in Arbil is a modern structure, so it does not have the same architectural characteristics as its surroundings and it has sharp lines. From this point of view, only the historic features of the area were taken as the value of the environment, and the architectural details of the zone were omitted.

\section{Conclusions}

It is important for urban and urban people to provide continuous care in the historical environment, to take measures by renewing and protecting neglected and uninterested areas, to re-evaluate and protect for today and future. The protected historic areas should not be regarded solely as cultural assets of societies, and it should not be ruled out that these historical sites are a universal consignment. As a result of the evaluations made, the Kurdish museum, which is the modern structure designed by Daniel Libeskind beside the historic Erbil castle, was built with the concept of memory and history concept. The Kurdish museum, which is a modern structure besides the stereotyped traditional architectural models, historical and cultural assets as the obstacles to the destruction of the revival of the society by making cultural exchanges are aimed to be transferred to the next generations.

\section{References}

[1] YAZGAN, M. E. ve ERDOĞAN, E., 1992. "Landscape Planning in Historical Environments". Publications of Landscape Architecture Association 2, Ankara.

[2] ARABACIOĞLU P., AYDEMİR I., (2007), "the concept of reconsideration in historical circles". E-Journal Volume 2, Issue 4, 2007) (ARABACIOĞLU and AYDEMİR).

[3] TAEBİ,A.BALA 2016. II. Uluslararası Kent Araştırmaları Kongresi Küresel ve Yerel Arasında Kentler: Stratejiler, F1rsatlar ve Sorunlar 11-13 May1s 2016 İstanbul.

[4] TEKELİ, İ. (1991). Urban Planning Talk, Ankara: TMMOB Chamber of Architects Publications.

[5] Korumaz M., Gulec Korumaz S.A., Canan F., 2011, "Examination of Authenticity of Re-Used Traditional Houses in the Centrum of Konya/Turkey", Second International Conference on the Constructed Environment, Second International Conference on the Constructed Environment, Chicago/USA (Oral Presentation). 
[6] ZEREN, N. (1984). Landscape Planning in Historical Environments".

[7] UNESCO, (1972). Recommendation concerning the Protection, at National Level, of the Cultural ant Natural Heritage (Kültürel ve Doğal Mirasın Ulusal düzeyde korunmasına İlişkin Tavsiyeler). UNESCO Genel Kurulu, 16 Kasım 1972, Paris. (http://whc.unesco.org/archive/convention-en.pdf), Erișim tarihi: 30.03.2012.

[8] UNESCO, (1976). Tarihi Alanların Korunması ve Çağdaş Rolleri Konusunda Tavsiyeler (Recommendation concerning the Safeguarding and Contemporary Role of historic Areas), UNESCO Genel Konferans1, 26 Kasım 1976, Nairobi. (http://portal.unesco.org/en/ev.php-

URL ID $=13133 \&$ URL DO=DO TOPIC \&URL

SECTION=201.html), Erişim tarihi: 30.03 .2012$.
[9] DAĞABAKAN, (2012). "Financial Resource Management in the Revitalization of Historic Areas: T.C. Ministry of Culture and Tourism Examples from the European Union and Recommendations for Turkey "http://libeskind.com/

[10] TATLICAN, G. (2006). The Importance of Cultural Investments in the Preservation of Urban Conservation Areas, Istanbul Fener and Balat Districts Model, Mimar Sinan Fine Arts University Institute of Science, Unpublished Master Thesis, Istanbul.

[11] Korumaz M., 2003, "Sculptural Water Elements of Traditional Buildings in Central and Southeastern Anatolia" CIB W62 2003. Water Supply and Drainage for Buildings, 29th International Symposium, 11-12 September 2003, Ankara / Turkey (Oral Presentation)

[12] Osma, http://www.yesiltopuklar.com/tarihi-cevrede-yeni-yapitasarlamak.html. 